\title{
Identification and characteristics of a novel cecropin from the armyworm, Mythimna separata
}

Kaiqi Lian", Mingliang Zhang, Xiuli Liang, Lingling Zhou, Zhiqi Shi, Yajie Tang, Xueping Wang, Yuwei Song and Yuanchen Zhang ${ }^{*}$

\begin{abstract}
Background: The recent emergence of antibiotic-resistant strains of bacteria has increased the need to develop effective alternatives to antibiotics. Antimicrobial peptides have been considered as a promising product with several advantages.

Results: In this present study, we identified a novel cecropin from the armyworm, Mythimna separata (armyworm cecropin 1, AC-1) by transcriptome sequencing and multi-sequence alignment analysis. The AC-1 precursor comprised 63 amino acid residues, containing a conserved cleavage site of the signal peptide, $\mathrm{Ala}_{23}-\mathrm{PrO}_{24}$, while the mature AC-1 included 39 amino acid residues. Chemically synthesized AC-1 exhibited low hemolytic activity against chicken red blood cells, low cytotoxicity against swine testis cells, and effective antimicrobial activity against Salmonella, Escherichia coli, Klebsiella pneumonia, and Pseudomonas aeruginosa. Its antimicrobial activity against Salmonella remained after incubation for $1 \mathrm{~h}$ at $100^{\circ} \mathrm{C}$ or in $250 \mathrm{mM} \mathrm{NaCl}, \mathrm{KCl}$, or $\mathrm{MgCl}_{2}$ solution, implying good thermal- and salt-resistant stabilities. The bactericidal effect of AC-1 on E. coli gradually increased with increasing AC-1 concentration, resulting in deformation, severe edema, cytolysis, cell membrane damage, and reducing intracellular electron density. Additionally, recombinant AC-1 protein expressed in E. coli was digested by enterokinase protease to obtain AC-1, which showed similar antimicrobial activity against E. coli to chemically synthesized AC-1.
\end{abstract}

Conclusions: This study identified a novel antimicrobial peptide that may represent a potential alternative to antibiotics.

Keywords: Antimicrobial peptide, Armyworm, Antimicrobial activity, Cecropin

\section{Background}

The long-term overuse of conventional antibiotics has led to an increase in multidrug-resistant bacteria in animals and humans, including methicillin-resistant Staphylococcus aureus (MRSA), highlighting the need for useful alternatives to antibiotics for controlling and treating the resulting bacterial diseases [1]. Antimicrobial peptides (AMPs) are important components of natural immunity

\footnotetext{
*Correspondence: liankaiqi616@163.com; zhangyuanchen0110@163.com Henan Joint International Research Laboratory of Veterinary Biologics Research and Application, School of Biotechnology and Food Science, Anyang Institute of Technology, No.73 Huanghe Road, Anyang, Henan 225009, People's Republic of China
}

that are widely distributed in insects, mammals, amphibians, fish, plants, and bacteria [2-4]. AMPs exert activities against microorganisms, including bacteria, viruses, parasites, and fungi $[5,6]$, and have thus received much attention as potential antibiotic substitutes.

Researchers have accordingly discovered many novel AMPs in different species using various techniques, with the aim of identifying useful AMPs to substitute for traditional antibiotics to prevent and control bacterial infections. Insects do not display adaptive immunity but do possess an effective self-defense system similar to mammalian innate immunity $[7,8]$. AMPs are important

(c) The Author(s). 2020 Open Access This article is licensed under a Creative Commons Attribution 4.0 International License, which permits use, sharing, adaptation, distribution and reproduction in any medium or format, as long as you give appropriate credit to the original author(s) and the source, provide a link to the Creative Commons licence, and indicate if changes were made. The images or other third party material in this article are included in the article's Creative Commons licence, unless indicated otherwise in a credit line to the material. If material is not included in the article's Creative Commons licence and your intended use is not permitted by statutory regulation or exceeds the permitted use, you will need to obtain permission directly from the copyright holder. To view a copy of this licence, visit http://creativecommons.org/licenses/by/4.0/ The Creative Commons Public Domain Dedication waiver (http://creativecommons.org/publicdomain/zero/1.0/) applies to the data made available in this article, unless otherwise stated in a credit line to the data. 
part of the insect defense system, and can directly kill pathogenic microorganisms or activate other immune pathways to clear pathogens [9]. Over 200 kinds of AMPs have been identified in insects to date, including about 30 kinds of cecropins. In the current study, we investigated a novel insect cecropin in the armyworm, Mythimna separata, named armyworm cecropin 1 (AC1 ), and predicted and analyzed its physicochemical characteristics and structure. We also evaluated the hemolytic activities, cytotoxicity, and in vitro antimicrobial activities of chemically synthesized AC-1, and expressed recombinant $\mathrm{AC}-1$ using and Escherichia coli prokaryotic expression system.

\section{Results}

\section{Identification of AC-1}

Transcriptome sequencing of the armyworm was performed to obtain a gene pool, which was compared with the published AMP sequence. A novel cecropin was identified in the armyworm, and its gene and amino acid sequences are shown in Fig. 1. The gene sequence of the novel AMP was confirmed by polymerase chain reaction (PCR) amplification and gene sequencing. The open reading frame of the novel AMP was $192 \mathrm{bp}$ in length and was translated into 63 amino acid residues. A conserved cleavage site was predicted in the signal peptide at $\mathrm{Ala}_{23}-\mathrm{Pro}_{24}$ using the SignalP-5.0 Server (http://www. cbs.dtu.dk/services/SignalP/). Multi-sequence alignment indicated that the cleavage site at $\mathrm{Ala}_{23}-\mathrm{Pro}_{24}$ was conserved among cecropins from many insects (Fig. 2). The mature peptide therefore comprised 39 amino acid residues, and was named armyworm cecropin-1 (AC-1). The amino acid sequence of AC-1 was highly similar to cecropins from other insects (Fig. 2).

\section{Physicochemical characteristics and secondary structure of AC-1}

The physicochemical characteristics of $\mathrm{AC}-1$ were predicted and shown in Table 1 . AC- 1 included 22 kinds of basic amino acid residues, and its secondary structure predicted using the online PEP-FOLD3 software suggested that AC-1 might adopt two $\alpha$-helix conformations $\left(\mathrm{Lys}_{5}-\mathrm{Met}_{13}\right.$, and $\mathrm{Ala}_{27}-\mathrm{Gly}_{38}$ ) (Fig. 3). The predicted secondary structure indicated an $\alpha$-helix content of AC-1 of $58.97 \%$, consistent with the predicted secondary structure of AC-1. We further analyzed the secondary structure of $\mathrm{AC}-1$ by detecting and analyzing its circular dichroism (CD) spectrum in phosphate buffer saline (PBS) using a CD spectrometer (Chirascan; Applied Photophysics Limited, United Kingdom). AC-1 existed in three main structural forms in a physiological environment (20 mM PBS, pH 7.4): anti-parallel (44.5\%), $\beta$ turn $(22.6 \%)$, and random coil (32.6\%) (Table 2).

\section{Hemolytic and cytotoxic activities of AC-1}

The hemolytic activities of AMPs need to be assessed prior to their use in clinical practice. Chemically synthesized AC-1 showed low hemolytic capacity against chicken red blood cells, and the hemolysis rate was only $14.47 \pm$ $1.03 \%$ even after treatment with AC- 1 at $500 \mu \mathrm{g} / \mathrm{mL}$ for 1 h (Fig. 4a). The cytotoxicity of AC-1 was determined in swine testis (ST) cells. The viability of the ST cells was not significantly influenced by AC-1, and the cell survival rate remained $>90 \%$ even after treatment with at $500 \mu \mathrm{g} / \mathrm{mL}$ AC-1 for $1 \mathrm{~h}$ (Fig. 4b). These results indicated that AC-1 had low hemolytic and cytotoxic activities.

\section{Antimicrobial activity of AC-1}

The antimicrobial activities of chemically synthesized AC-1 were evaluated in vitro by detecting the minimum inhibitory concentrations (MICs) using a standard twofold broth microdilution method. AC-1 exhibited antimicrobial activities against standard strains of Salmonella, E. coli, and Klebsiella pneumonia with MICs of < $20.00 \mu \mathrm{g} / \mathrm{mL}$, but did not inhibit Bacillus cereus or Staphylococcus aureus at $250.00 \mu \mathrm{g} / \mathrm{mL}$ (Table 3). AC-1 still showed antimicrobial activities against clinically

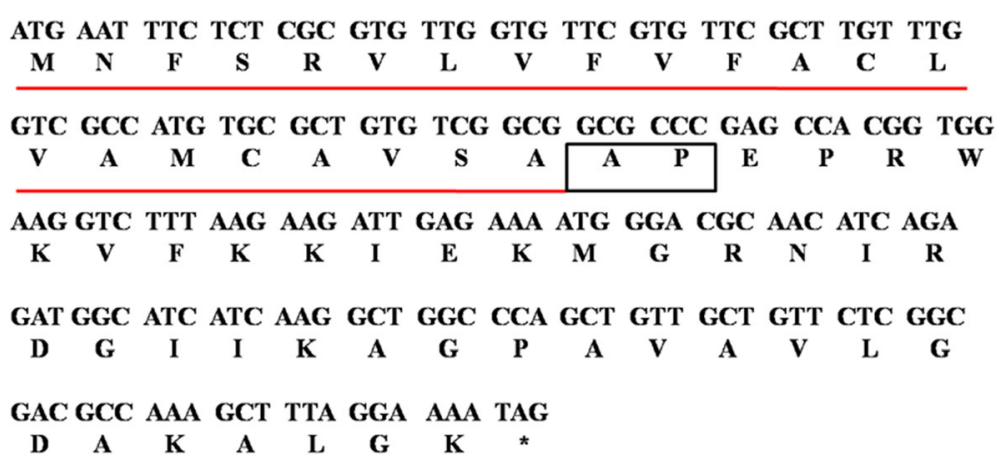

Fig. 1 Nucleotide and amino acid sequences of AC-1 precursor. Underlined amino acid residues indicate the signal peptide; boxed amino acid residues indicate the cleavage site of the signal peptide; asterisk indicates the stop codon. 


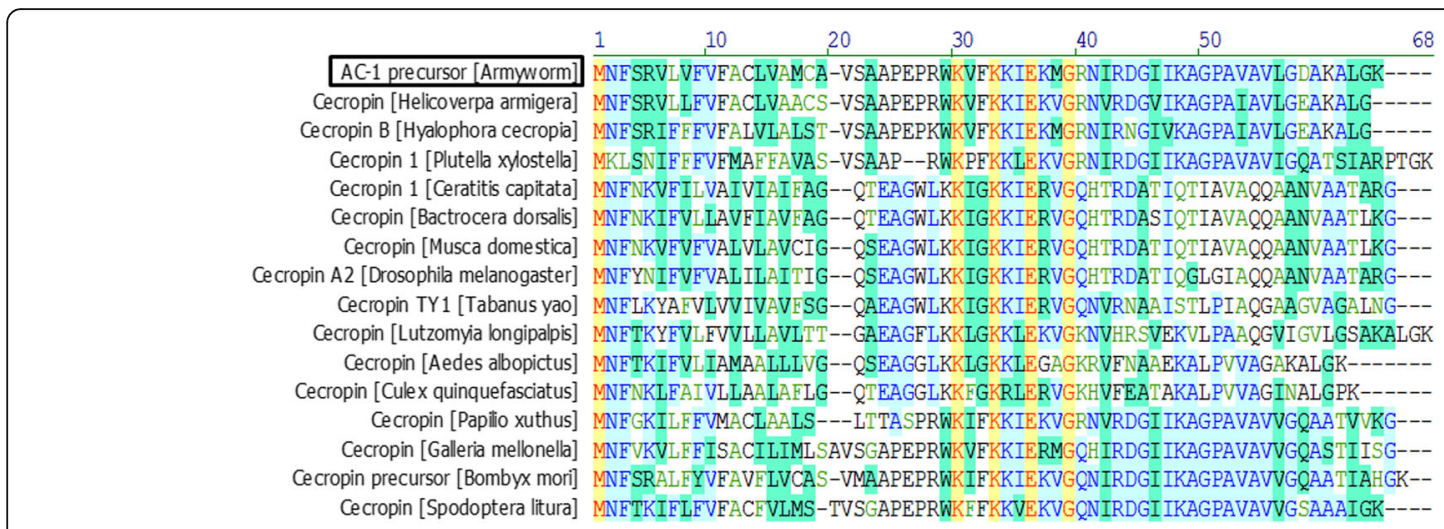

Fig. 2 Multi-sequence alignment of AC-1 with representative cecropins from other insects. The conserved Ala-Pro cleavage site is boxed; identical residues are marked in yellow and highly conserved residues in blue.

isolated Salmonella and E. coli with MICs of 31.25 and $25.00 \mu \mathrm{g} / \mathrm{mL}$, respectively (Table 3 ).

\section{Thermal- and salt-resistant stabilities of AC-1}

We further evaluated the thermal- and salt-resistant stabilities of AC- 1 by exposure to different temperatures, and $\mathrm{NaCl}, \mathrm{KCl}$, and $\mathrm{MgCl}_{2}$ concentrations for $1 \mathrm{~h}$. Treatment at temperatures ranging from 4 to $60^{\circ} \mathrm{C}$ had no obvious influence on the antimicrobial activities of $\mathrm{AC}-1$ against Salmonella; however, its activity was lower at $80^{\circ} \mathrm{C}$ and $100^{\circ} \mathrm{C}$, compared with $4{ }^{\circ} \mathrm{C}$ (Fig. 5a). The antimicrobial activities of AC-1 against Salmonella decreased with increasing $\mathrm{NaCl}, \mathrm{KCl}$, and $\mathrm{MgCl}_{2}$ concentrations from 0 $\mathrm{mM}$ to $250 \mathrm{mM}$, but the ability of AC-1 to inhibit Salmonella growth was not significantly decreased even at final concentrations of $250 \mathrm{mM} \mathrm{NaCl}, 250 \mathrm{mM} \mathrm{KCl}$, and 200 $\mathrm{mM} \mathrm{MgCl} 2$ for $1 \mathrm{~h}$ (Fig. $5 \mathrm{~b}-\mathrm{d}$ ). These results suggested that $\mathrm{AC}-1$ had good thermal- and salt-resistant stabilities.

\section{Antibacterial effect of AC-1 on E. coli}

In order to further study antibacterial activities of AC-1, the time killing curve of $\mathrm{AC}-1$ against $E$. coli was determined by the plate count method. The results showed that the bactericidal effect of AC-1 on E. coli gradually increased with increasing $\mathrm{AC}-1$ concentration, and with increasing the action time within $60 \mathrm{~min}$ (Fig. 6). Transmission electron microscopy (TEM) observation suggested that AC-1 resulted in significant deformation, severe edema, cytolysis, cell membrane damage of $E$. coli compared with the control group, together with decreased intracellular electron density (Fig. 7). These results indicated that AC-1 showed effectively antibacterial activity against $E$. coli.

\section{AC-1 expression in E. coli}

The chemical synthesis of peptide is expensive, and we therefore examined the expression of $\mathrm{AC}-1$ in $E$. coli using recombinant DNA technology. The results showed that recombinant $\mathrm{AC}-1$ was mainly expressed in inclusion bodies at 20 and $37^{\circ} \mathrm{C}$ (Fig. 8a). Recombinant AC-1 was purified using a Ni-NTA gravity column with imidazole eluent (50 mM imidazole) (Fig. 8b-c). However, determination of the MIC of recombinant AC-1 suggested that it had no antibacterial activity against $E$. coli. Therefore, recombinant $\mathrm{AC}-1$ was digested by enterokinase to produce AC-1 (Fig. 8d), which showed a MIC of $7.8 \mu \mathrm{g} /$ $\mathrm{mL}$ against $E$. coli ATCC 25922. These results indicated that $\mathrm{AC}-1$ could be prepared by an E. coli prokaryotic expression system.

\section{Discussion}

Several methods can be used to identify novel AMPs. Qi et al. found two novel AMPs in the frog Odorrana livida by PCR amplification, using primer pairs based on the highly conserved sequence of known cathelicidins [10]. Zhou et al. identified five novel AMPs from Hylarana guentheri by isolation and purification [11], and Ma et al. identified 34 AMPs from Rana nigrovittata by peptidomics and genomics [12]. Yang et al. also identified a novel cathelicidin from the Chinese giant salamander Andrias davidianus using transcriptome sequencing and PCR amplification [13]. In the current study, we identified a novel cecropin from the armyworm by transcriptome

Table 1 Physicochemical characterizations of the AC-1

\begin{tabular}{lccccc}
\hline Peptide & Grand average of hydropathicity & $\begin{array}{l}\text { Number of } \\
\text { amino acids }(n)\end{array}$ & $\begin{array}{l}\text { Net } \\
\text { charge }\end{array}$ & Theoretical pl & Molecular weight (Da) \\
\hline AC-1 & -0.321 & 39 & $6+$ & 10.38 & 4262.13 \\
\hline
\end{tabular}




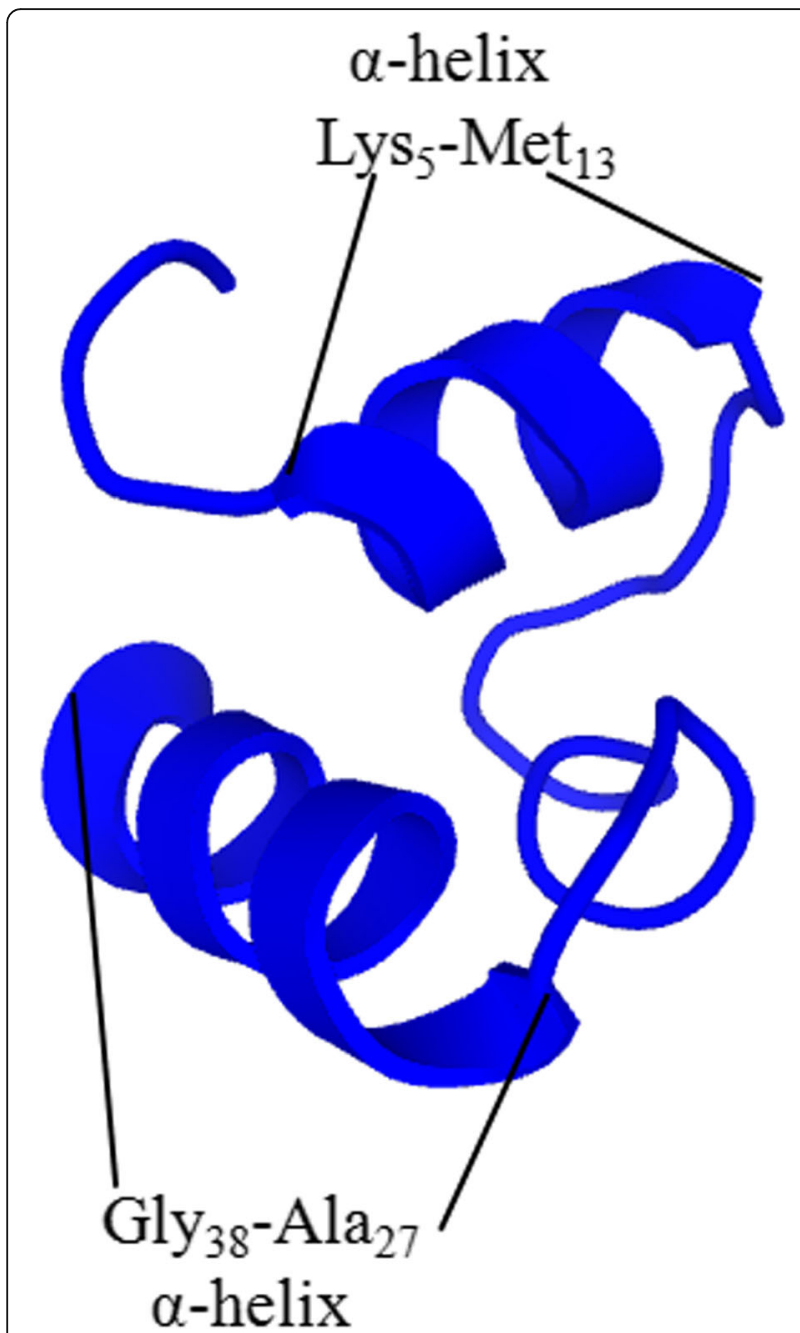

Fig. 3 Secondary structure of AC-1 predicted by the online software PEP-FOLD3.5.

sequencing and sequence alignment analysis. Sequencing of the PCR-amplified product confirmed the identity of the novel armyworm cecropin gene. Developments in high-throughput sequencing techniques have led to the discovery of increasing amounts of genetic data among which underlying AMPs are being increasingly identified.

Multi-sequence alignment and biological software analysis showed that the amino acid sequence of $\mathrm{AC}-1$ was highly homologous to cecropins from other insects, and its precursor included the conserved signal peptide AlaPro cleavage site upstream of the mature peptide [14, 15]. In addition, AC-1 included the RWK and FKKIE(L) KVG structural domains that are conserved in cecropins from lepidopterous insects. Cecropins usually have a small molecular mass, positive charge, and $\alpha$-helix conformation [15]. The physicochemical characteristics and predicted secondary structure of AC-1 were consistent with those of cecropins. The theoretical pI value of AC1 was 10.38 , which was $>9$, suggesting that AC-1 would have a positive charge under physiological conditions [10].

In this study, we evaluated the antimicrobial, hemolytic, and cytotoxic activities, and the thermal- and salt-resistant stabilities of chemically synthesized AC-1. However, chemically synthesized AC-1 peptide is currently expensive, and may have reduced antimicrobial activities. It is therefore necessary to develop an efficient method for producing clinically useful peptides using a prokaryotic or eukaryotic expression method. Wang et al. produced the cecropin pxCECA1 in E. coli [15], while Pei et al. generated the antimicrobial peptide MDAP-2 using an E. coli prokaryotic expression system [16]. Li et al. expressed the peptide CGA-N46 in Bacillus subtilis DB1342 [17]. Luiz et al. produced the abaecin peptide [18] and $\mathrm{Li}$ et al. expressed the antimicrobial peptide fowlicidin-2, both in Pichia pastoris [19]. In the current study, we expressed recombinant AC-1 using an E. coli prokaryotic expression system, and the AC-1 obtained by enterokinase digestion exhibited similar antimicrobial activity to chemically synthesized AC-1.

\section{Conclusions}

In conclusion, we identified a novel cecropin $\mathrm{AC}-1$ from armyworms, which showed effective antimicrobial activities and low hemolytic and cytotoxic activities, as well as good thermal- and salt-resistant stabilities, implying that AC-1 may be clinically useful for preventing and treating bacterial diseases. We also successfully prepared AC-1 using an E. coli prokaryotic expression system and enterokinase digestion. Further studies are needed to determine the antimicrobial mechanisms and in vivo antimicrobial activities of AC-1.

Table 2 Percentages of the secondary structural elements of AC-1 in PBS (20 mmol/L, pH 7.4)

\begin{tabular}{llllll}
\hline & $190-260 \mathrm{~nm}$ & $195-260 \mathrm{~nm}$ & $200-260 \mathrm{~nm}$ & $205-260 \mathrm{~nm}$ & $210-260 \mathrm{~nm}$ \\
\hline Helix & $6.9 \%$ & $6.9 \%$ & $7.6 \%$ & $8.6 \%$ & $10.7 \%$ \\
Anti-parallel & $44.5 \%$ & $40.3 \%$ & $53.7 \%$ & $52.1 \%$ & $44.4 \%$ \\
Parallel & $2.7 \%$ & $3.6 \%$ & $4.4 \%$ & $4.8 \%$ & $5.2 \%$ \\
Beta-Turn & $22.6 \%$ & $23.0 \%$ & $24.7 \%$ & $24.5 \%$ & $22.1 \%$ \\
Random.Coil & $32.6 \%$ & $34.1 \%$ & $31.6 \%$ & $29.6 \%$ & $33.5 \%$ \\
Total Sum & $109.3 \%$ & $107.9 \%$ & $121.9 \%$ & $119.6 \%$ & $115.9 \%$ \\
\hline
\end{tabular}



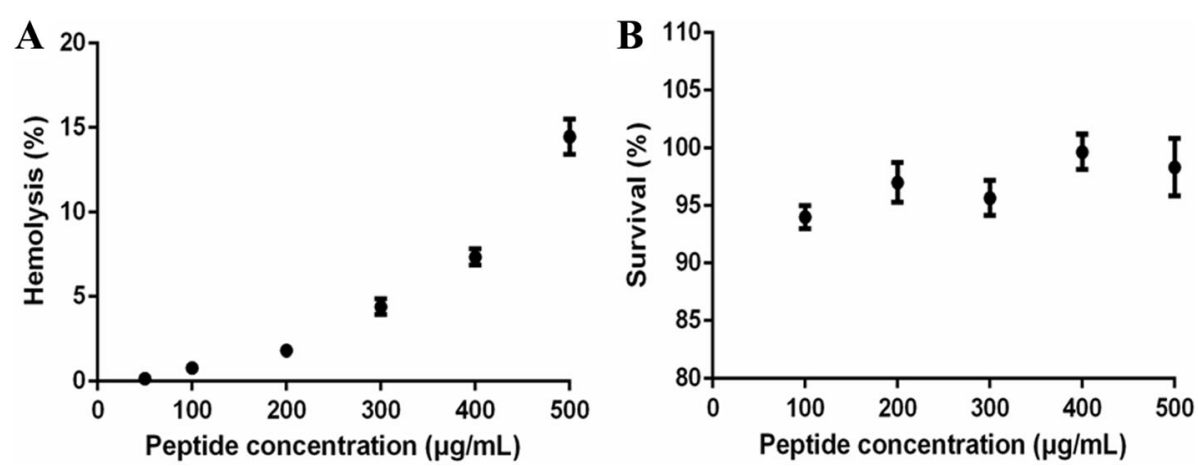

Fig. 4 Hemolytic and cytotoxic activities of AC-1. a: Hemolytic activity of AC-1 evaluated in chicken red blood cells. b: Cytotoxic activity of AC-1 evaluated in swine testis cells.

\section{Methods}

\section{Identification of antimicrobial peptide}

Third instar larvae of the armyworm Mythimna separata were ground in liquid nitrogen and total RNA was extracted for transcriptomesequencing. The known AMP gene sequence was selected to align the transcriptomesequence using MegAlign software. The primers were designed based on the armyworm gene acquired by sequence alignment (sense primer: 5'-TTTGAATTAA GAACAAT-3'; antisense primer: 5'-CTATTTTCCT AAAGCTT-3'). The gene was amplified by PCR using the above primers with Premix LA Taq (Takara, Dalian, China) according to the manufacturer's instructions. The PCR conditions were as follows: denaturation at $94{ }^{\circ} \mathrm{C}$ for $4 \mathrm{~min}, 36$ cycles of denaturation at $94{ }^{\circ} \mathrm{C}$ for 40 s, annealing at $57^{\circ} \mathrm{C}$ for $35 \mathrm{~s}$, and elongation at $68^{\circ} \mathrm{C}$ for $25 \mathrm{~s}$, and a final elongation at $68^{\circ} \mathrm{C}$ for $8 \mathrm{~min}$. The PCRamplified products were cloned into the pMD18-T vector (Takara) and positive plasmids were sequenced.

\section{Multi-sequence alignment of cecropins from different insects}

The amino acid sequence of the AC-1 precursor was derived from the nucleotide sequence and subjected to multi-sequence alignment with the respective cecropins of different insects from the protein database at the National Center for Biotechnology Information (NCBI, https://www.ncbi.nlm.nih.gov/protein/?term=cecropin) using Vector NTI Advance 11.5 .3 software.

\section{Physicochemical characteristics and structure prediction of $\mathrm{AC}-1$}

The physicochemical characteristics of AC-1 were predicted by the ExPASy Bioinformatics Resource Portal (http://www.expasy.org/tools/) and its secondary structure was predicted using a novel online computational framework PEP-FOLD3.5 (http://bioserv.rpbs.univ-parisdiderot.fr/services/PEP-FOLD3/) [20]. The secondary structural components of AC-1 were calculated using an online SOPMA secondary structure prediction method (https://npsa-prabi.ibcp.fr/cgi-bin/npsa_automat.

pl?page=npsa_sopma.html).

We further analyze the secondary structure of AC-1 by examining its $C D$ spectrum, $(0.2 \mathrm{mg} / \mathrm{mL})$ in $20 \mathrm{mM}$ PBS (pH 7.4) using a CD spectrometer (Chirascan, Applied Photophysics Limited, United Kingdom). The CD spectrum of AC-1 was recorded between 190 and 260

Table 3 Minimum inhibitory concentration $(\mu \mathrm{g} / \mathrm{mL})$ of the AC-1 and ampicillin against microorganisms

\begin{tabular}{|c|c|c|}
\hline \multicolumn{2}{|l|}{ Microorganisms } & $\begin{array}{l}\text { MIC }(\mu \mathrm{g} / \mathrm{mL}) \\
\text { AC-1 Ampicillin }\end{array}$ \\
\hline \multirow[t]{6}{*}{ Gram negative bacteria } & Escherichia coli ATCC25922 & $7.80(1.83 \mu \mathrm{mol} / \mathrm{L}) 0.50$ \\
\hline & Escherichia coli clinical strain & $25.00(5.87 \mu \mathrm{mol} / \mathrm{L})>250.00$ \\
\hline & Salmonella ATCC13076 & $12.50(2.93 \mu \mathrm{mol} / \mathrm{L}) 1.00$ \\
\hline & Salmonella clinical strain & $31.25(7.33 \mu \mathrm{mol} / \mathrm{L})>125.00$ \\
\hline & Klebsiella pneumonia ATCC27853 & $15.63(3.67 \mu \mathrm{mol} / \mathrm{L})-$ \\
\hline & Pseudomonasaeruginosa ATCC700603 & $125.00(29.33 \mu \mathrm{mol} / \mathrm{L})>62.50$ \\
\hline \multirow[t]{2}{*}{ Gram positive bacteria } & Bacillus cereus ATCC11778 & $>250.00(58.66 \mu \mathrm{mol} / \mathrm{L})-$ \\
\hline & Staphylococcus aureus ATCC29213 & $>250.00(58.66 \mu \mathrm{mol} / \mathrm{L}) 0.50$ \\
\hline
\end{tabular}

$>$, no activity detected at the concentration indicated. -, not assayed. Gram positive bacteria 

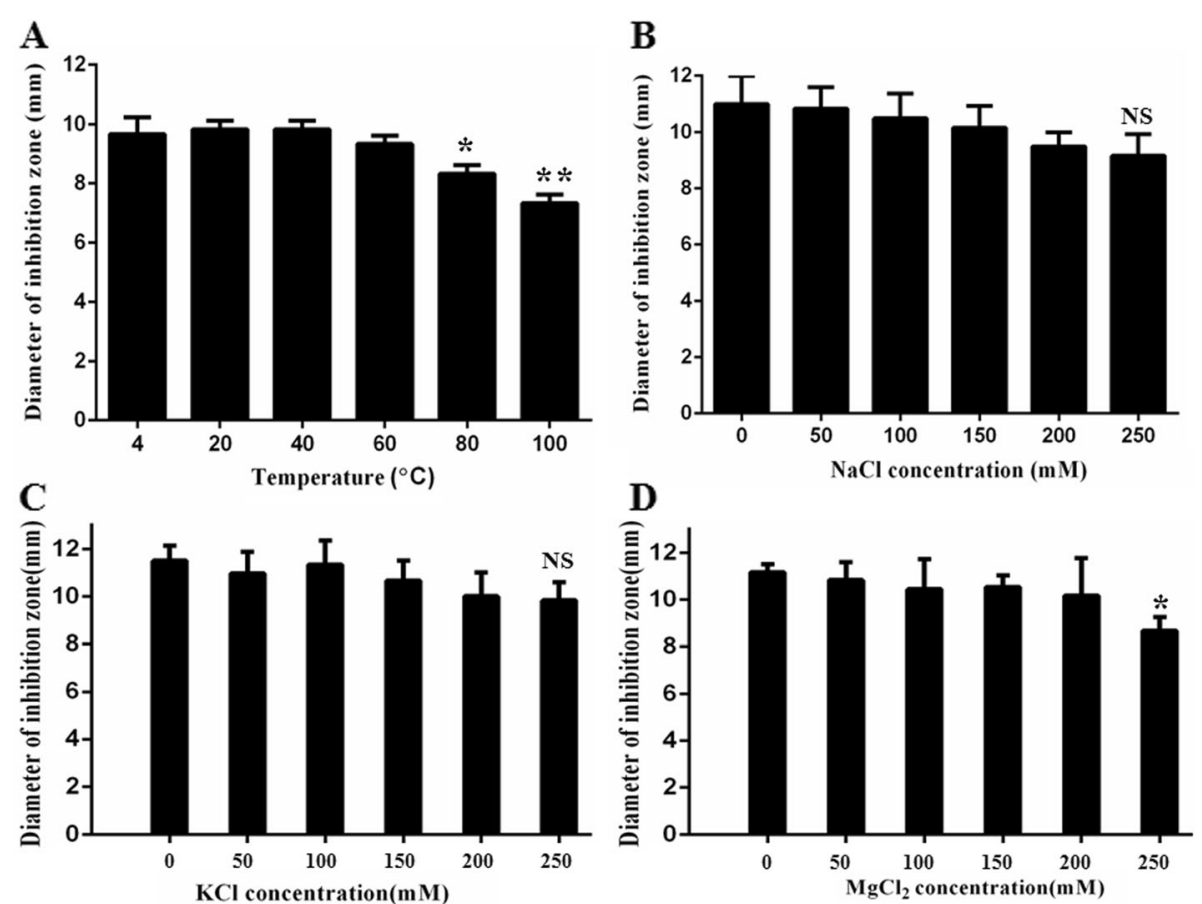

Fig. 5 Thermal- and salt-resistant stabilities of AC-1. a: Thermal-resistant and (b-d) salt-resistant stabilities of AC-1 determined by detecting the antimicrobial activities of AC-1 against Salmonella (ATCC13076). ${ }^{*} p<0.05 \mathrm{and} \mathrm{N}^{* *} p<0.01$, compared with treatment at $40{ }^{\circ} \mathrm{C}$ or $0 \mathrm{mM} \mathrm{MgCl}$. NS indicates no significance, compared with the control.

$\mathrm{nm}$ at $1 \mathrm{~nm}$ intervals at room temperature, with a $0.5 \mathrm{~s}$ response time and $1.0 \mathrm{~nm}$ step size.

\section{Hemolytic and cytotoxic activities of AC-1}

AC-1 (purity > 98\%) was synthesized by Shanghai Gil Biochemical Co., Ltd., China, purified by reverse highperformance liquid chromatography (Figure S1), and detected by mass spectrometry (Figure S2). Its hemolytic activity was tested using blood drawn from chickens and treated with sodium citrate anticoagulant. The treated blood was centrifuged at $3000 \times g$ for $10 \mathrm{~min}$ and washed three times in PBS. The red blood cells were counted and diluted to $2 \times 10^{7} / \mathrm{mL}$, and $100 \mu \mathrm{L}$ of red blood cell suspension was mixed with $100 \mu \mathrm{L}$ of different concentrations of AC-1 (final concentrations: $50,100,200,300,400$, and $500 \mu \mathrm{g} / \mathrm{mL}$ ). Triton X-100 solution was as a positive control and PBS as a negative control. After incubation for $1 \mathrm{~h}$ at $37^{\circ} \mathrm{C}$, the mixture was centrifuged at $3000 \times g$ for 10 min and the absorbance of the supernatants was then detected at $405 \mathrm{~nm}\left(\mathrm{OD}_{405}\right)$. The hemolysis ratio was calculated by the formula: hemolysis ratio $=\left(A_{405 \text { peptide }}\right.$ - $\left.\mathrm{A}_{405 \mathrm{PBS}}\right) /\left(\mathrm{A}_{405 T \text { Triton }}-\mathrm{A}_{405 \mathrm{PBS}}\right) \times 100 \%$. Each experiment was repeated three times.

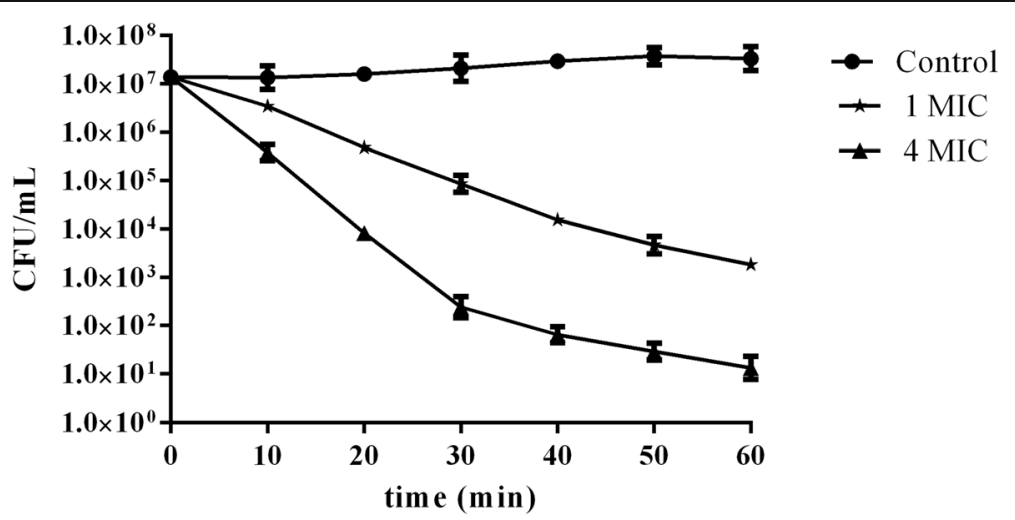

Fig. 6 Time killing curve of AC-1 against E. coli. 

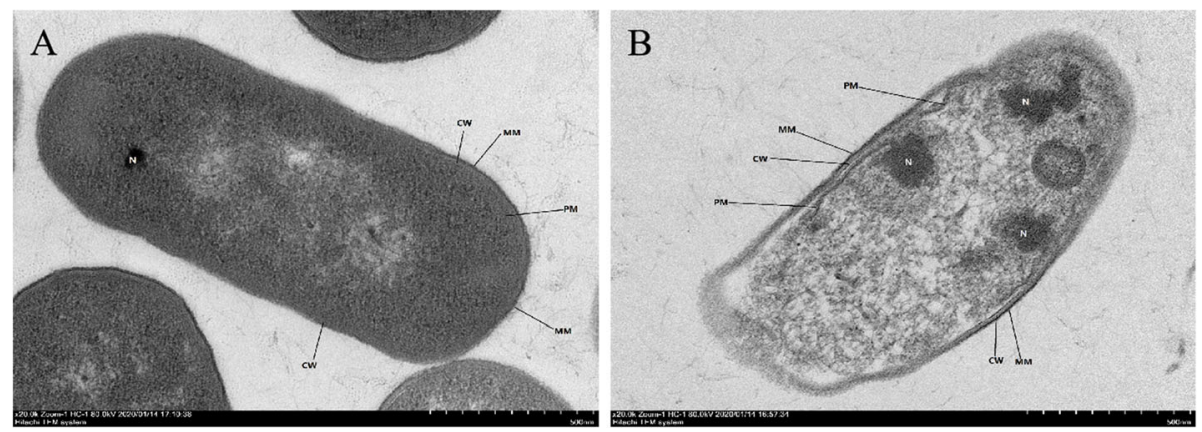

Fig. 7 Transmission electron microscopy observation of E. coli treated with $0.9 \% \mathrm{NaCl}$ solution (a) or 4 MIC AC-1 (b).

The cytotoxicity of AC-1 was evaluated using a CCK-8 cell counting kit (Vazyme, Nanjing, China) in ST cells as described previously, with minor modifications [21]. A total of $100 \mu \mathrm{L}$ of cells (about $5 \times 10^{4}$ / $\mathrm{mL}$ ) per well was added into 96-well cell-culture plates and incubated for $24 \mathrm{~h}$ at $37^{\circ} \mathrm{C}$. Different concentrations of AC-1 (final concentrations: 100, 200, 300,400 , and $500 \mu \mathrm{g} / \mathrm{mL}$ ) were added to the cells with further incubation for $12 \mathrm{~h}$ at $37^{\circ} \mathrm{C}$, followed by the addition of $10 \mu \mathrm{L}$ of CCK- 8 reagent into each well. The cell-culture plates were incubated for $1 \mathrm{~h}$ at $37^{\circ} \mathrm{C}$ and the absorbance was determined at $450 \mathrm{~nm}$ using an automatic microplate reader. Each experiment was repeated three times.

\section{Antimicrobial assay of AC-1}

The antimicrobial activity of AC-1 was analyzed by determining the MIC against different bacteria, as described previously, with minor modifications [22]. Ampicillin was used as a positive control. The synthesized AC-1 was dissolved in PBS and added into 96-well microtiter plates at two-fold dilutions. All the bacterial strains were cultured in Luria-Bertani (LB) broth at $37^{\circ} \mathrm{C}$ to exponential phase. The bacterialsolutions were diluted to $2 \times 10^{6}$ colony forming units (CFUs) $/ \mathrm{mL}$ and added to 96 -well microtiter plates at $50 \mu \mathrm{L}$ per well, followed by $100 \mu \mathrm{L}$ of AC-1/bacteria solution with mixing, and incubated for $16 \mathrm{~h}$ at $37^{\circ} \mathrm{C}$. Resazurin $(10 \mu \mathrm{L} 6$ $\mathrm{mM}$ ) was then added to each well and incubated for a

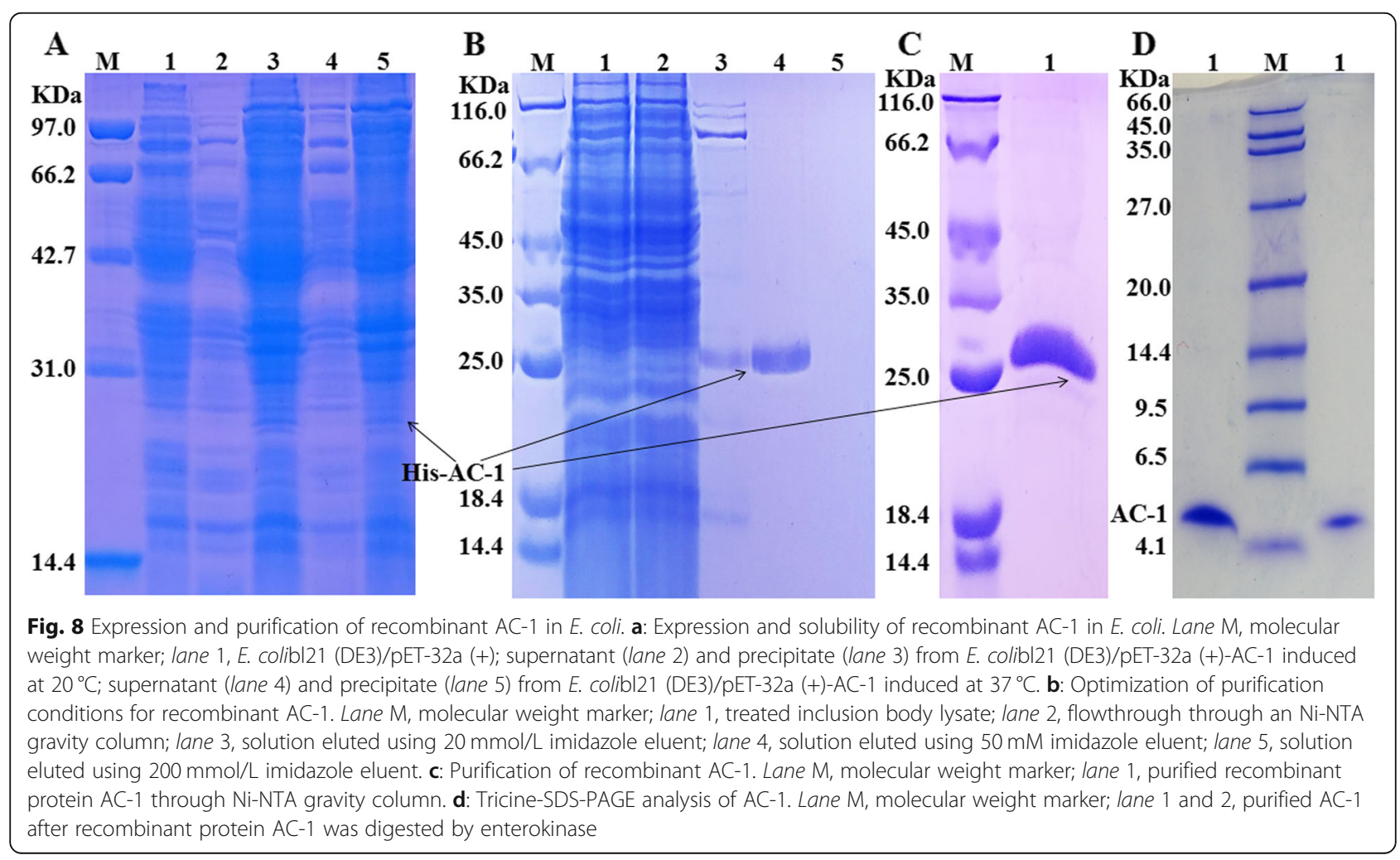


further $3 \mathrm{~h}$ and the color change was observed in each well. Ampicillin and kanamycin were used as positive controls and PBS and LB broth as negative controls. The MIC was recorded as the concentration of the peptide in the last well that remained blue.

\section{Thermal- and salt-resistant stabilities of AC-1}

We evaluated the thermal- and salt-resistant stabilities of $\mathrm{AC}-1$ by determining the antimicrobial activities of AC-1 against Salmonella according to the inhibition zone method. To assess its thermal-resistant stability, 1 $\mathrm{mg} / \mathrm{mL} \mathrm{AC-1}$ was incubated for $1 \mathrm{~h}$ at $4,20,40,60,80$, and $100{ }^{\circ} \mathrm{C}$, respectively. To determine its salt-resistant stability, $1 \mathrm{mg} / \mathrm{mL} \mathrm{AC-1}$ was incubated for $1 \mathrm{~h}$ with 0 , $50,100,150,200$, and $250 \mathrm{mM}$ of $\mathrm{NaCl}, \mathrm{KCl}$, and $\mathrm{MgCl}_{2}$, respectively. Salmonella was cultured to exponential phasein LB broth at $37^{\circ} \mathrm{C}$ and diluted to $2 \times 10^{9} \mathrm{CFUs} /$ $\mathrm{mL}$. Diluted bacterial solution $(100 \mu \mathrm{L})$ was then mixed with $100 \mathrm{~mL}$ of sterilized LB solid medium and poured into a sterile culture dish. After cooling, the culture dish was punched using a diameter-same hole punch. The treated AC-1 solution was added into each well. Ampicillin was used as a positive control and PBS as a negative control. The culture dishes were incubated at $37^{\circ} \mathrm{C}$ for $12 \mathrm{~h}$ and the diameters of the inhibition zones were measured using Vernier calipers. Each experiment was carried out in triplicate.

\section{Time killing curve of AC-1 against E. coli}

Time killing curve of AC-1 against E. coli was determined as described previously [23]. E. coli in logarithmic growth phase were centrifuged to collect the precipitate, diluted with sterile LB liquid medium to $2 \times 10^{7} \mathrm{CFU} /$ $\mathrm{mL}$, followed by the addition and mixing of $400 \mu \mathrm{L}$ of bacterial solution and $400 \mu \mathrm{L}$ of $\mathrm{AC}-1$ solution to final concentrations of $\mathrm{AC}-1$ of $1 \mathrm{MIC}$ and $4 \mathrm{MIC}$, respectively. $\mathrm{NaCl}$ solution was used as negative control. The mixed solution was incubated at $37^{\circ} \mathrm{C}$ for $0,10,20,30$, $40,50,60 \mathrm{~min}$, respectively, and then centrifuged to collect the bacteria. The bacterial precipitate was washed and suspended in PBS, and $50 \mu \mathrm{L}$ of bacterial solution was serially diluted 10 times. Each dilution of bacterial solution $(100 \mu \mathrm{L})$ was spread on LB plates and cultured for $14 \mathrm{~h}$, and the number of bacteria was then calculated. Each experiment was carried out in triplicate.

\section{TEM}

E. coli in logarithmic growth phase were centrifuged to collect the precipitate. The precipitate was washed three times with sterile PBS and diluted with sterile PBS to $2 \times 10^{7} \mathrm{CFU} / \mathrm{mL}$, and $600 \mu \mathrm{L}$ of bacterial solution and $600 \mu \mathrm{L}$ of $\mathrm{AC}-1$ solution were thoroughly mixed, to give a final concentration of $\mathrm{AC}-1$ of $4 \mathrm{MIC}$. The mixed was incubated in a water bath at $37^{\circ} \mathrm{C}$ for $1 \mathrm{~h}$. E. coli treated with $\mathrm{NaCl}$ solution was used as a negative control. The two groups of E. coli were fixed, dehydrated, and stained, as described previously [24], and examined by TEM (HT7700; Hitachi, Japan).

\section{Expression of AC-1 in E. coli}

The recombinant AC-1 gene included 39 amino acid residues of the mature peptide $\mathrm{AC}-1$ and the enterokinase cleavage site at $5^{\prime}$-terminus of $\mathrm{AC}-1$ gene. $\mathrm{AC}-1$ gene was synthesized and cloned into pET-32a (+) using the restriction enzymes Kpn I and Hind III. The recombinant plasmid pET-32a (+)-AC-1 was transformed into E. coli BL21 (DE3) to express recombinant AC-1 by isopropyl- $\beta$-D-thiogalactoside induction. The resulting recombinant protein was purified using a Ni-NTA gravity column as described previous [25], and then digested using enterokinase. The digested solution was passed through a Ni-NTA gravity column, and the flowthrough was collected, dialysed, and concentrated to obtain AC-1 as described previous [25].

\section{Statistical analysis}

Data were analyzed using GraphPad Prism 6 software. A value of $p<0.05$ was considered significant and $p<0.01$ was considered highly significant.

\section{Supplementary information}

Supplementary information accompanies this paper at https://doi.org/10. 1186/s12866-020-01925-1.

Additional file 1: Figure S1. Purification of chemically synthesized AC1 by reverse-high performance liquid chromatography.

Additional file 2: Figure S2. Detection of chemically synthesized AC-1 by mass spectrometry.

\section{Abbreviations}

E.coli: Escherichia coli; MRSA: Methicillin-resistant Staphylococcus aureus; AMP: Antimicrobial peptide; PCR: Polymerase chain reaction; CD: Circular dichroism; ST cell: Swine testis cell; MIC: Minimum inhibitory concentration; mM: mmol/L; TEM: Transmission electron microscopy; NCBI: National Center for Biotechnology Information; PBS: Phosphate buffer saline; CFU: Colony forming units; LB: Luria-Bertani

\section{Acknowledgments}

We thank PhD Shuai Wang from Lanzhou Veterinary Research Institute, Chinese Academy of Agricultural Sciences for help to predict the peptide structure.

\section{Authors' contributions}

K.Q.L. and Y.C.Z. designed the study and analyzed the data. L.L.Z. amplified and analyzed the AC gene. M.L.Z. performed the physicochemical characterizations and structure analysis. X.L.L. performed hemolytic and cytotoxic activities experiments. Y.J.T. performed the multi-sequence alignment analysis. Z.Q.S. performed the antimicrobial activity and thermalresistant and salt-resistant stability experiments. Y.W.S. participated in experiment design. K.Q.L., Y.C.Z., X.P.W. and Y.J.T. wrote and revised the paper. All authors approved the final manuscript.

\section{Funding}

This work was supported by the following funding: the National Natural Sciences Foundation of China (31802170), Colleges Key Scientific Research 
Projects of Henan Province (19B230001), Postdoctoral Research Fund for Anyang Institute of Technology (BHJ2020005). These three funding bodies provided funds for the purchase of consumption materials for the study but had no role in the design of the study and collection, analysis, and interpretation of data and writing of the manuscript.

\section{Availability of data and materials}

All data generated or analyzed during this study are included in this published article and its supplementary information files.

\section{Ethics approval and consent to participate}

Not applicable.

\section{Consent for publication}

Not applicable.

\section{Competing interests}

The authors declare that there are no competing interests.

Received: 18 November 2019 Accepted: 27 July 2020

Published online: 01 August 2020

\section{References}

1. Brauner A, Fridman O, Gefen O, Balaban NQ. Distinguishing between resistance, tolerance and persistence to antibiotic treatment. Nat Rev Microbiol. 2016:14(5):320-30.

2. Ganz T. The role of antimicrobial peptides in innate immunity. Integr Comp Biol. 2003:43(2):300-4

3. Jenssen H, Hamill P, Hancock RE. Peptide antimicrobial agents. Clin Microbiol Rev. 2006;19(3):491-511.

4. Bahar AA, Ren D. Antimicrobial peptides. Pharmaceuticals. 2013;6(12):154375

5. Nguyen LT, Haney EF, Vogel HJ. The expanding scope of antimicrobial peptide structures and their modes of action. Trends Biotechnol. 2011;29(9): 464-72.

6. Guani-Guerra E, Santos-Mendoza T, Lugo-Reyes SO, Teran LM. Antimicrobial peptides: general overview and clinical implications in human health and disease. Clin Immunol. 2010;135(1):1-11.

7. Ip YT. Drosophila innate immunity goes viral. Nat Immunol. 2005;6(9):863-4.

8. Hoffmann JA, Kafatos FC, Janeway CA, Ezekowitz RA. Phylogenetic perspectives in innate immunity. Science. 1999;284(5418):1313-8.

9. Slocinska M, Marciniak P, Rosinski G. Insects antiviral and anticancer peptides: new leads for the future? Protein Peptide Letters. 2008;15(6):57885

10. Qi RH, Chen Y, Guo ZL, Zhang F, Fang Z, Huang K, Yu HN, Wang YP. Identification and characterization of two novel cathelicidins from the frog Odorrana livida. Zool Res. 2019;40(2):94-101.

11. Zhou J, McClean S, Thompson A, Zhang Y, Shaw C, Rao P, Bjourson AJ. Purification and characterization of novel antimicrobial peptides from the skin secretion of Hylarana guentheri. Peptides. 2006;27(12):3077-84.

12. Ma Y, Liu C, Liu X, Wu J, Yang H, Wang Y, Li J, Yu H, Lai R. Peptidomics and genomics analysis of novel antimicrobial peptides from the frog, Rana nigrovittata. Genomics. 2010;95(1):66-71.

13. Yang $H$, Lu B, Zhou D, Zhao L, Song W, Wang L. Identification of the first cathelicidin gene from skin of Chinese giant salamanders Andrias davidianus with its potent antimicrobial activity. Dev Comp Immunol. 2017; 77:141-9.

14. Barandoc KP, Kim J, Kim Y. Cotesia plutellae bracovirus suppresses expression of an antimicrobial peptide, cecropin, in the diamondback moth Plutella xylostella, challenged by bacteria. J Microbiol. 2010;48(1):117-23.

15. Wang $\mathrm{H}$, Meng XL, Xu JP, Wang J, Wang H, Ma CW. Production, purification, and characterization of the cecropin from Plutella xylostella, pxCECA1, using an intein-induced self-cleavable system in Escherichia coli. Appl Microbiol Biotechnol. 2012:94(4):1031-9.

16. Pei Z, Sun X, Tang Y, Wang K, Gao Y, Ma H. Cloning, expression, and purification of a new antimicrobial peptide gene from Musca domestica larva. Gene. 2014;549(1):41-5

17. Li RF, Wang B, Liu S, Chen SH, Yu GH, Yang SY, Huang L, Yin YL, Lu ZF. Optimization of the expression conditions of CGA-N46 in Bacillus subtilis DB1342(p-3N46) by response surface methodology. Interdisciplinary Sci Comput Life Sci. 2016;8(3):277-83.
18. Luiz DP, Almeida JF, Goulart LR, Nicolau-Junior N, Ueira-Vieira C. Heterologous expression of abaecin peptide from Apis mellifera in Pichia pastoris. Microb Cell Factories. 2017;16(1):76.

19. Xing LW, Tian SX, Gao W, Yang N, Qu P, Liu D, Jiao J, Wang J, Feng XJ. Recombinant expression and biological characterization of the antimicrobial peptide fowlicidin-2 in Pichia pastoris. Exp Ther Med. 2016;12(4):2324-30.

20. Lamiable A, Thevenet P, Rey J, Vavrusa M, Derreumaux P, Tuffery P. PEPFOLD3: faster de novo structure prediction for linear peptides in solution and in complex. Nucleic Acids Res. 2016;44(W1):W449-54.

21. Zhang Q, Xu Y, Wang Q, Hang B, Sun Y, Wei X, Hu J. Potential of novel antimicrobial peptide P3 from bovine erythrocytes and its analogs to disrupt bacterial membranes in vitro and display activity against drugresistant bacteria in a mouse model. Antimicrob Agents Chemother. 2015; 59(5):2835-41.

22. Dong Z, Luo W, Zhong H, Wang M, Song Y, Deng S, Zhang Y. Molecular cloning and characterization of antimicrobial peptides from skin of Hylarana guentheri. Acta Biochim Biophys Sin. 2017:49(5):450-7.

23. Wang L, Zhao XQ, Xia XJ, Zhu CL, Qin WH, Xu YZ, Hang BL, Sun YW, Chen SJ, Zhang HH. JiangJQ, Fotina $H$, Zhang GP: antimicrobial peptide $\mathrm{JH}-3$ effectively kills Salmonella enterica Serovar Typhimurium strain CVCC541 and reduces its pathogenicity in mice. Probiotics Antimicrobial Proteins. 2019; 11(4):1379-90.

24. Wang XM, Teng D, Mao RY, Yang N, Hao Y, Wang JH. Combined systems approaches reveal a multistage mode of action of a marine antimicrobial peptide against pathogenic Escherichia coli and its protective effect against bacterial peritonitis and Endotoxemia. Antimicrob Agents Chemother. 2017. 61(1):e01056-16

25. Xu YZ, Wang Q, Hang BL, Fu DF, Shang TT, Zhao ZY, Zhang QH, Hu JH. Serial expression and activity analysis of LNK-16: a bovine antimicrobial peptide analogue. Protein J. 2014;33(4):309-12.

\section{Publisher's Note}

Springer Nature remains neutral with regard to jurisdictional claims in published maps and institutional affiliations.

Ready to submit your research? Choose BMC and benefit from:

- fast, convenient online submission

- thorough peer review by experienced researchers in your field

- rapid publication on acceptance

- support for research data, including large and complex data types

- gold Open Access which fosters wider collaboration and increased citations

- maximum visibility for your research: over $100 \mathrm{M}$ website views per year

At BMC, research is always in progress.

Learn more biomedcentral.com/submissions 